\title{
Meretas Konflik Sains Dan Agama (Dalam Perspektif Amin Abdullah dan Ian G. Barbour)
}

\author{
Muhaini \\ muhaini@iainlangsa.ac.id \\ IAIN Langsa
}

\begin{abstract}
The last few decades Institut for Islamic Studies (PTKI) has transformed from conventional systems and models to modern ways including the learning approaches as well as curriculum. PTKI is Khithah as the centre of Islamic studies in a new model, it expands its function not only as a center of the study of faith and traditions but also to explore Islam as a source of rules social living and also the source of knowledge for many years is led by Muslim scientists. The spirit of transformation is not to be wordclass university only but how to carry out the mandate of the integration of knowledge which has long been convinced by the PTKI community. This paper presents two figures of the integration model who is well known among PTKI lecturers, Amin Abdullah and Ian G. Barbour, they mediate the conflict between science dan religion.
\end{abstract}

\section{Keyword: Dialogue, Integration, Interconected}

Abstrak: Beberapa dekade terakhir PTKI beranjak dari konvensional sistem dan model kepada sistem dan model termasuk pendekatan pembelajaran dan kurikulumnya. PTKI yang khihtahnya adalah sebagai pusat kajian kajian keislaman kini melebarkan fungsinya tidak hanya sebagai sumber imani dan nalar di tengahtengah hiruk-pikuk modernisasi teknologi dan pengetahuan tetapi juga terus menelusuri Islam sebagai sumber aturan kehidupan (sosial) sekaligus sumber ilmu pengetahuan yang selama ini terpisah dan ditinggalkan oleh ilmuwan muslim. Kini PTKI dengan spirit transformasi tidak hanya sebagai alasan utama menjadikan wordclass university tetapi juga mengemban amanah integrasi ilmu yang sudah lama diyakini kebenarannya oleh para masyarakat PTKI. Tulisan ini memaparkan dua tokoh model integrasi yang sangat dikenal dikalangan dosendosen PTKI yaitu Amin Abdullah dan Ian G. Barbour bagaimana mereka menjadi mediasi konflik antarsain dan agama.

\section{Kata Kunci: Dialog, Integrasi, Interkoneksi}

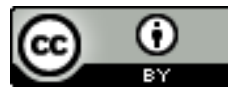

This work is licensed under a Creative Commons Attribution 4.0 International License 


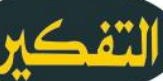

PENDAHULUAN

Ki Hajar Dewantara, tokoh pendidikan Nasional mengatakan pendidikan adalah sesungguh sungguhnya dan menanamkan akhlak, kecerdasan (intelektualitas), kesehatan fisik demi mempersiapkan kehidupan dan fungsinya di tengah tengah masyarakatnya (Azra, 2002). Menurut Mohd. Natsir yang dimaksud dengan pendidikan, ialah suatu bimbingan jasmani dan ruhani mencapai kesempurnaan manusia dengan arti sesungguhnya (Azra, 2002). Intinya pendidikan adalah mempersiapkan generasi untuk menjalankan kehidupan dan memenuhi tujuan hidupnya secara lebih efektif dan efisien (Azra, 2002).

Tidak jauh berbeda dengan platform sistem Pendidikan Nasional RI menyatakan Pendidikan adalah usaha sadar yang direncana, dirancang untuk menciptakan suasana bagi peserta didik dapat secara aktif ngembangkan potensi dirinya untuk memiliki spiritual keagamaan, mngelola diri baik itu kepribadian, kecerdasan, akhlak mulia, serta keahlian yang bermanfaat baik untuk dirinya, masyarakat, bangsa dan Negara (UU Sisdiknas 2003). Jika memahami UU Sistem Pendidikan Nasional jelas tampak sekali bahwa pendidikan adalah untuk mempersiapkan anak yang memiliki kepribadian yang sesuai dengan jati diri bangsa. Namun faktanya strategi yang telah dirumuskan perlu dikaji ulang atau dengan bahasa lain perlu disempurnakan dengan kepentingan yang sangat urgen sehingga pemangku kepentingan pendidikan dalam hal ini masyarakat Indonesia tidak melihat potret buram pendidikan yang masih menimbulkan tanda tanya besar di tanah air terutama dalam karakter anak bangsa yang telah melalui proses pendidikan baik disektor formal maupun non formal.

Ada beberapa alasan dalam mengapa hal ini terjadi, pertama, jam-jam pelajaran keagamaan sangat minim baik di sekolah-sekolah maupun di tingkat universitas terutama pada PTUN. Kedua visi misi yang sangat baik yang membangun karakter tetapi masih belum didukung dengan kurikuler yang sifatnya membangun paradigm ilmu yang mendialogkan kedua eksistensi sain dan agama termasuk kehidupan sosial masih berangkat dari epistimologi, ontologi dan aksiologi masih adanya dikhotomi, seharusnya sain dan agama dapat Jurnal At-Tafkir: Volume 13 Nomor 1 Tahun 2020

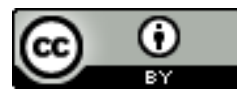

This work is licensed under a Creative Commons Attribution 4.0 International License 
saling mendukung untuk saling mengisi demi membangun keilmuan dan karakter anak bangsa.

Selama ini agama hanya disikapi dan diperlakukan hanya sebatas ajaran dogmatis dan sakral dan wajib untuk dipelajari saja tetapi tidak terkoneksi bahkan kurang integratif dengan ilmu ilmu lain seperti ilmu alam dan social, atau gap antara ayat-ayat kauliyah dan ayat-ayat kauniyah. Ilmu-ilmu agama tidak memikat sebagai kajian ilmiah karena dilepaskan dari kehidupan. Sementara ilmu-ilmu alam maju pesat tidak menyentuh spiritualitas keagamaan, sehingga disamping kehilangan hakekat fungsi ilmu itu sendiri dan bisa merusak sendisendi kehidupan (Team, Kerangka Dasar Keilmuan dan Pengembangan Kurikulum 2006) padahal perkembangan pemikiran ilmu oleh filosopf Muslim besar meletakkan eksitensi Tuhan dalam keberadaannya ilmu syariyah dan ilmu ghairu syar'iyah bagi Imam al-Gazali dan ilmu al-Ulum naqliyah dan al-Ulum aqliyah bagi Ibnu Khaldun. Kedua Filosof muslim tersebut menyatukan konsep ilmu keilmuan yang bersifat analitik emperik dengan konsep ilmu agama yang memilki peran masing-masing hanya menjeniskan keduanya bukan memisahaka apalagi penolakan validitas dari masing-masing ilmu. Banyak penulis dan peneliti pada zaman Dinasti Abbasiyah bermunculan ilmuan muslim dengan berbgai keahliannya, mereka tidak hanya ahli dalam ilmu pengetahuan dan sain tetapi mereka juga ahli dalam agama diantaranya adalah $\mathrm{Al}-$ Kindi, Filsuf dari Arab, dia memiliki keahlian bidang filsafat, teologi dan matematika, Al-Farabi, karya utamanya tentang logika antara lain: komentar pada Analitytica Posteriora, Analytica Priora, Isagoge, Tipica, Shopistica, De Interppretatione, dan De Cateoriare. Ibnu Sina, terkenal dengan Avecenna, sebagai dokter dan filsuf. Ibn Rusyd, seorang dokter, ahli hukum, dan tokoh filsuf yang paling menonjol dikenal dengan nama Averros. Sejak kecil telah mempelajari Al-Qur'an, lalu mempelajari ilmu-ilmu keislaman, seperti tafsir, Hadis, fiqih, dan sastra Arab. Seterusnya ia mendalami matematika, fisika astronomi, logika, filsafat, dan ilmu kedokteran, Bidayatul Mujtahid, Kulliyat fi Tibb, Al-Khawarizmi, ia seorang ahli matematika metode menghitung logaritma dan juga mempelopori penggunaan angka nol. AlBiruni, ia ahli matematika, fisika, geologi, geografi dan filsafat. Menguasai banyak bahasa, Arab, Parsia, Yunani, Ibrani, dan Suryani. Umar Khayam, Beliau adalah

Jurnal At-Tafkir: Volume 13 Nomor 1 Tahun 2020

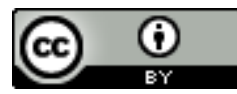

This work is licensed under a Creative Commons Attribution 4.0 International License 
seorang penyair besar, sufi, filsuf, ahli matematika, ahli astronomi. Umar Khayam menulis buku al-Jabr, buku matematika terpenting pada Abad Pertengahan. Ibnu Qurroh (826 M-901 M) menguasai astronomi dan matematika. Al Battani (858 M$929 \mathrm{M}$ ) atau yang lebih mashur nama Albategnius adalah ahli matematika dan astronom, ilmuwan yang pertama kali mengenalkan fungsi trigonometri, berupa: sinus, cosinus, tangens, secan, cosecan dan cotangens. Di bidang astronomi, beliaulah ilmuwan yang paling pertama kali berhasil mengukur peredaran waktu dalam satu tahun masehi secara teliti, yaitu : 365 hari 5 jam 46 menit 24 detik. Ilmuwan Muslim lainnya adalah Ar Razi (865 M925 M) lebih populer dengan nama latin Rhazes. Beliau ahli kedokteran klinis dan kimia. Az Zahrawi (936 M-1013 M) atau lebih dikenal dengan nama latin Albucasis, ahli kedokteran umum dan kedokteran gigi. Al Buzjani (940 M - 997 M) ahli dalam bidang matematika dan astronomi. beliau juga menulis 'Ilm Al-Hisab (aritmatika) dan 'Ilm Al Handasah (geometri) (Haidar, 2015).

Pemandangan sain dan agama pada dunia Islam pada masa klasik sangat kontras dengan sejarah perkembangan sains dan agama di eropa yang pernah terjadi di kalangan agamawan atau rohaniawan (Paus) dengan ilmuwan sebelum masa renaissance pada abad ke-13 di Barat. Terutama dalam hal kosmologi, Nicolaus Copernicus (1473-1543), yang menemukan bahwa matahari adalah pusat alam semesta (helionsentris), bertolak belakang dengan pandangan umum yang didomonasi oleh geraja bahwa alam semesta ini adalah geosentris yang dikemukankan oleh ahli astronomi Yunani Kuno yang bernama Hipparchus pada tahun 140 SM (sebelum Masehi). Konsep geosentris yang lebih ilmiah juga dikemukan oleh Cladius Ptolemaeus sekitar 150 TM (Tarikh Masehi) seorang yunani yang bertempat tinggal di Mesir. Kalangan gereja waktu itu menganggap bahwa bumi sebagai tempat tinggal manusia pilihan Tuhan sehingga bumi harus menjadi pusat alam semesta (Tjasyono dan Syukur, 2014) Perselisihan dan pertentangan antara kaum gereja ortodok dan ilmuwan Kristen tidak bisa didamaikan. Sebaliknya gereja mengutuk para ilmuwan dan filosof dengan menyebut mereka sebagai pembid'ah bahkan murtad serta gerakan averroisme adalah sesat (Haidar, 2015) Walaupun pada masa itu muncul konsep penyeimbang menganut kebenaran ganda (double 
truth) mereka tidak tidak mau lagi terikat oleh otoritas gereja, ilmuwan berjalan dengan logika ilmiah. Kelompok konservatif ini menolak kebenaran kitab suci yang ditafsirkan tunggal oleh pihak gereja. Mereka pada umumnya adalah penganut paham averroisme, menolak dengan tegas doktrin-doktrin agama oleh gereja tokohnya adalah John Jandun. Ia beranggapan bahwa doktrin-doktrin gereja bertentangan dengan akal. Bahkan ia menyatakan bahwa Kristen tidak harus percaya bahwa Tuhan menciptakan alam.

Pada tahun 1233 M Paus Gregorius IX mengeluarkan perintah untuk membunuh para filosof dan ilmuwan yang bertentangan dengan gereja. Semenjak Tahun 1252-1277 M oleh Paus Inocent teolog-teolog Kristen mencurigai temuantemuan ilmuwan yang sudah memisahkan agama dari ilmu pengetahuan (Haidar, 2015). Bahkan Menurut catatan selama 18 tahun semenjak tahun 1481-1499 Ilmuwan yang dibakar hidup-hidup sebanyak 10.220 orang, 6.869 orang digantung dan 97.023 dihukum dengan berbagai macam siksaan dan hukuman (Haidar, 2015). Sejak diresmikan oleh gereja pada 1481 M hingga 1801, inkuisisi telah mengeksekusi tidak kurang dari 340.000 orang. Hampir 32.000 di antaranya dibakar hidup-hidup (Abduh, 1992).

Tokoh-tokoh ilmuwan yang terkenal itu di antaranya adalah: Roger Bacon (1214-1292), Girolano Savonorola yang dihukum mati oleh Paus Alexsander VI pada tahun 1498. Hermann Van Reeswijk seorang tokoh averrois dari Den Haag yang menjalani hukuman mati dengan dibakar hidup-hidup pada 14 Desember 1512 sebelumnya ia dipenjara kemudian dilempar ke api, sebelum dilempar ia sempat mengatakan bahwa Aristoteles dan Ibn Rusyd adalah sarjana yang paling besar (Iqbal,2006). Kemarahan gereja juga terhadap Ilmuwan Nicolaus Copernicus yang menentang Claudius Ptolemeus. Cladius menyatakan bahwa bumi merupakan sumbu putar tata surya, sedang matahari berputar mengelilingi matahari dalam bukunya yang berjudul The revolution of the heavenly Bodies. Pendapat Claudius Ptolemeus pada saat itu secara resmi dianut oleh gereja. Johanens Kepler (1571-1630) yang menemukan tiga macam hukum gerak bagi planet-planet, yaitu pertama membuat gerakan eleptikal dengan matahari sebagai salah satu apinya. Kedua, garis yang menghubungkan pusat planet dengan matahari dalam Jurnal At-Tafkir: Volume 13 Nomor 1 Tahun 2020

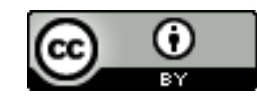

This work is licensed under a Creative Commons Attribution 4.0 International License 


\section{난}

waktu yang sama akan membentuk bidang yang sama luasnya. Ketiga, kuadrat priode planet mengelilingi matahari sebanding dengan pangkat tiga dari rata-rata jaraknya terhadap matahari. Galileo Galilei seorang astronom menyatakan kesamaan pandangannya dengan Nikolas Kopernikus, dan gereja marah terhadap temuan mereka. Kemarahan gereja juga kepada pengikutnya Nicolaus Copernicus, dan Giardano Bruno (1548-1600 M) yang menyatakan bahwa matahari adalah sumbu putar tata surya, oleh sebab itu mereka dianggap heretic (pembid'ah dan murtad) dipenjara dan akhirnya tewas. Dalam catatan Hasyimsah mengambil dari Ahmad Fuad dalam bukunya al-Falasafah al Islamiyah, Romenas dipenjara hingga mati kemudian mayatnya dibakar, karena ia mengatakan bahwa pelangi adalah refleksi sinar cahaya matahari ke atas air, bukan seperti kepercayaan gereja bahwa pelangi diciptakan Tuhan untuk menyerang hambahamba-Nya yang keluar dari ajaran agama Hasyimsah, 1999).

Sikap kebencian pada ilmuwan dan pengetahuan yang ditunjukan oleh penganut paham gereja ortodok tidak menghentikan langkah para kalangan ilmuwan. Dengan isu semangat ilmu pengetahuan di Barat (renaisans) juga semakin gencar melawan gereja bahkan mereka benci terhadap gereja dan ajarannya di sinilah mereka mulai menunjukan perlawanan atas ideologi atau paham ajaran gereja dengan cara memisahkan paham gereja dengan ilmu pengetahuan. Mereka (para ilmuwan Kristen Barat) menyatakan bahwa alam ini tidak diciptakan oleh Tuhan bahkan mereka mencurigai kekuasaan Tuhan sebagai pencipta dan pengatur alam, karena hal ini dianggap tidak ilmiah, di sinilah cikal bakalnya timbul sekuler di dunia Barat.

Keingkaran lain dari ilmuwan adalah Laplace juga terlihat jelas, bahwa Laplace tidak melibatkan Tuhan sama sekali.ketika menjelaskan terjadinya alam dan mekanisme benda-benda angkasa dalam karya beliau yang berjudul Celestial Mechanics. Sang singa eropa Napoleon menyadari dan kemudian menanyakan perihal tersebut pada sang astronom, seperti yang dikutip oleh Mulyadhi di dalam Dictionary of Philosophy yang ditulis oleh Antony Flew dia menjawab “Je n' ai pas besoin de cet hypothese", yang artinya "(Tuan)“ bahwa dia tidak membutuhkan 
hypothesa seperti itu melibatkan Tuhan (Haidar, 2015). Demikian juga Charles Darwin ahli Biologi yang terkenal karena teori evolusinya atau hukum seleksi alamiah (natural selection), Darwin tidak mempercayai keberadaan Tuhan, karena terpengaruh oleh pandangan ilmiahnya. Dalam otobiografinya, dia menyatakan “

"Argumen desain selama ini dirasakan sangat meyakinkan ternyata telah gagal. Kini hukum seleksi alamiah telah ditemukan. Sekarang ini kita tidak dapat lagi mengatakan engsel kerang yang indah misalnya, harus merupakan hasil perbuatan yang wujud cerdas (Tuhan), sebagaimana engsel pintu harus merupakan hasil perbuatan manusia" (Mulyadhi, 2017)

Pertentangan yang begitu terbuka pada satu agama dalam hal ini gereja tidak biasa menerima pandangan ilmiah, pada sisi lain membuka lebar kesenjangan antara ilmuwan sekuler dengan agama. Dalam persfektif pandangan Islam ini sangat berbahaya secara aqidah jika ada ilmuan muslim yang tidak percaya akan ayat-ayat kauniyah.

Bangunan ilmu bagi masyarakat sekuler adalah terletak pada supremasi akal merupakan alat penting untuk memperoleh pengetahuan dan agama disingkirkan. Barat hanya membatasi objek kajian pengetahuan pada entitas fisik, maka alat yang digunakan adalah indra fisik, sain adalah segala sesuatu sejauh ia dapat diobesrvasi oleh indra, alasannya objek ilmu secara objektif dapat diverifikasi kebenarannya. Masyarakat Barat matrilisme, positivisme yang menjadi pijakan sain modern yang didasarkan atas pandanga ontologis yang realis. Positivisme menganggap pengetahuan mengenai fakta objektif merupaka pengetahuan yang dianggap paling shahih melampui fakta lama, tidak ada lagi perbincangan tentang etik ataupun metafisik setelah positivisme. Pandangan positivistik pertama harus objektif, dimana teori harus bebas nilai, kedua fenomenalisme di mana ilmu pengetahuan hanya bicara tentang semesta yang dapat diamati, substansi metafis yang berada dibalik gejala-gejala disingkirkan. Ketiga, reduksionisme di mana semesta direduksi menjadi fakta-fakta keras, bakau dapat diamati. Keempat. Naturalisme di mana alam semesta adalah objekobjek yang bergerak secara mekanisme seperti kerjanya jam. Kaum emperisme meyakini bahwa alam adalah segala sesuatu yang hadir melalui data indrawi, Jurnal At-Tafkir: Volume 13 Nomor 1 Tahun 2020

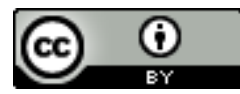

This work is licensed under a Creative Commons Attribution 4.0 International License 


\section{<}

dengan kata lain pengetahuan harus berawal dari pengamatan emperis, kalangan positivisme puncak pengetahuan manusia adalah ilmu berdasarkan fakta-fakta keras. Persoalan yang sangat mendasar adalah, ketika sains Barat memandang keagamaan yang berbicara tentang hal-hal gaib maka ilmu tidak bisa dipandang ilmiah karena ilmu-ilmu tersebut baru bisa dikatakan ilmiah apabila objekobjeknya bersifat emperis, padahal ilmu agama pasti akan berbicara hal-hal gaib, seperti Tuhan, malaikat, dan sebagainya (Mulyadhi, 20017).

Pemisahan ilmu dari aspek keagamaan ini pada gilirannya telah menimbulkan problem teologis yang krusial, karena lama kelamaan banyak ilmuwan Barat tidak merasa perlu lagi menyinggung atau melibatkan Tuhan sedikitpun dalam penjelasan keilmuwan merekan. Bagi mereka, Tuhan seolah olah telah berhenti menjadi apapun, termasuk menjadi pencipta dan pemelihara alam semesta. Sebagai contoh yang dikemukakan Pierre Simon de Laplace, adalah seorang Prancis di kenal dengan free thinker (pemikir bebas tulen) ( Haidar, 2015). Tentu saja sikap ilmuwan seperti itu tidak bersinergi dengan sikap dan kepribadian masyarakat Indonesia yang relegius dan selalu percaya dengan sepenuh hati bahwa alam semesta tak lain kecuali ciptaan dan tanda kebesaran ayatNya. Mereka (masyarakat relegius seperti Indonesia) juga percaya bahwa sumber ilmu serta metodenya tidak terbatas hanya pada observasi, tetapi juga akal, intuisi dan wahyu.

\section{METODE PENELITIAN}

Ulasan pada artikel ini menggunakan metode telaah kepustakaan (lybrary research) dengan pendekatan kualitatif deskriptif. Informasi diperoleh dari bukubuku, karya ilmiah dan referensi lain yang mendukung telaah kepustakaan yang dilakukan. Teori penelitian yang digunakan bersumber dari teori dialogis dan integrasi (Ian G. Barbour) serta integrasi-interkoneksi (Amin Abdullah). Konsep tersebut memberi solusi ketegangan antara sain yang besekukuh terhadap positivistik dan agama dikuasai oleh tafsir tunggal. Analisis data mengikuti 
tahapan pengumpulan data, reduksi data, penyajian data, dan penarikan kesimpulan serta verifikasi.

\section{HASIL PENELITIAN}

\section{A. Upaya PTKI Pengembangan Keilmuan di Perguruan Tinggi keagamaan Pendidikan Islam}

Perkembangan lembaga Perguruaan Tinggi Keagamaan Islam beberapa tahun ini sangat cepat dan juga sangat baik dari segi kuantitas dan kualitasnya. Dari segi kuantitasnya perkembangan PTKIN mencapai $3.61 \%$ secara nasional data BPS 2008-2014 (Gardiner 2017). Jumlah dan dosen di lingkungan perguruan tinggi Islampun terus meningkat drastis baik kualitasnya dengan strata pendidikan maupun jumlah dosen diPTKIN seiring dengan pertumbuhan dan bertranformasinya STAIN dan IAIN menjadi UIN.

PTKIN sebagai lembaga pendidikan Tinggi keislaman tidak hanya menggali, mendalami dan mempelajari Islam dari sumbernya dan peristiwa yang mengintarinya tetapi juga Islam melalui Alquran dan hadis yang diimani sebagai sumber ilmu pengetahuan yang harus digali ditelusuri melalui ilmu pengetahuan sebagai kewajiban muslim memahami fenemona alam semesta, melihat ayat-ayat dan tanda-tanda kebesaran Allah. Ada beberapa hal penting bagi para ilmuwan Muslim Indonesia terkait dengan Islam sebagai agama mayoritas bangsa Indoensia, pertama Islam melalui Alquran dan hadis dipahami masih dipahami sebagai tolak ukur ibadah saja, ilmu-ilmu keislaman yang telah seperti fiqih usuhuluddin (Kalam), falsafah Islam, nahwu, balaghah, ulumul Quran, Ulumul hadis tasawuf yang sudah mendominasi di PTKI kini kurang begitu tertatarik untuk memahami asumsi dasar, kerangka teori, paradigma, epistimolgi cara kerja dan struktur fundamental keilmuan yang melatarbelakangi dibangunnya ilmuilmu tersebut.

Oleh sebab PTKI sebagai ujung tombak pengembangan keilmuan Islam tidak ingin memisahkan antara agama dan ilmu pengetahuan yang keniscayaanya berkembang pesat dan membangun ilmu-ilmu mandiri. PTKI menginginkan menghilangkan dikhotomi disharmoni antara ilmu pengetehuan dan agama 
(Islam) melalui integrasi keilmuan, yaitu cara pandang tertentu atau model pendekatan tertentu terhadap ilmu pengetahuan yang bersifat menyatukan, melihat sesuatu ilmu sebagai bagian dari keseluruhan dan pandangan terhadap ilmu bersifat terbuka, siap untuk sharing dan berdialog atau mengapresiasi keberadaan lainnya (Kusmana, 2006). Alasan itu lah yang menjadi landasan utama mengapa IAIN bertransformasi menjadi UIN yaitu untuk menghilangkan dikhotomi antara ilmu agama dengan ilmu umum karena Islam adalah agama yang universal, oleh sebab itu perlu upaya mengintegrasikan secara kelembagaan pengembangan program studi di luar ilmu-ilmu keislaman. Hal senada juga pada UIN Syarif Hidaytullah yang menentukan sikap berkenaan dengan hubungan antara agama (Islam) dan dengan ilmu Pengetahuan, yaitu meresponi disharmonisasi (protes Ilmu Pengetahuan atau superioritas agama dalam upaya pemisahan atau dikhotomi antara urusan agama dan ilmu pengetahuan). Reharmonisasi adalah upaya ihtiyar Islamisasi ilmu pengetahuan atau integrasi keilmuan islam atau sering disebut dengan Integrasi Ilmu Pengetahuan ( Kusmana, 2006). Kini PTKI di berbagai daerah, baik yang sudah bertarnsformasi menjadi UIN atau belum, bahwa STAIN-IAIN bukan sekedar memperkaya jabatan-jabatan struktural tetapi ada cita-cita dan harapan serta tanggung jawab besar ketika mereka menuntut perubahan atau bertransformasi.

\section{Integrasi dan Interkoneksitas dalam sain dan Agama Amin Abdullah}

Konsep integrasi dan interkoneksi Amin Abdullah adalah berawal atas kegelisahan beliau terhadap bangunan keilmuan keislaman yang menurut beliau dikotomis-atomistik, bayani, irfani dan burhani (Amin, 2006) yang memiliki autoritas masing-masing apa yang beliau sebut dengan single entity (Amin, 2006). akibatnya akan terbentuk kepribadian yang split of personality (Amin, 2006). Pemahaman model yang demikian menurut beliau sulit dan rigid untuk menjawab masalahmasalah kontemporer, dengan ide integrasi dan interkoneksi Amin ingin membangun keilmuwan yang bersifat teoantroposentris, beliau juga menginginkan dediferensiasi antar agama dan ilmu pengetahuan, maka pergulatan beliau dalam 
memahami terhadap persoalan yang belum tuntas bahkan menimbulkan masalah baru dalam rangka bangun ilmu terutama di PTKI beliau melahirkan ide besar "integrasi dan interkoneksi" untuk meretas dikotomi antara sains dan agama, ilmu agama dan ilmu umum, sakral dan profan (Amin , 2005).

Dalam pandangan Amin abdulah yang dimaksud dengan integratif adalah terpadunya kebenaran wahyu (burhani), apa disebut dengan hadrati al-Nash, hadhrataul ilmu dan hadratul al-fasafah (etik). Sedangkan yang dimaksud dengan interkoneksi dapat dipahami sebagai sebuah bentuk hubungan saling mengisi dan melengkapi antara elemen-elemen sains dan agama dengan maksud untuk memperkuat sebuah kinerja penelitian dan pengembangan dalam mengkaji sebuah realitas (Amril, 2017). Secara etimologis, kata interkoneksi berarti hubungan satu sama lain, interkoneksitas adalah meleburkan hingga menjadi kesatuan yang utuh atau bulat (SKB 2 Mentri, 2004).

Interkonektif adalah terkaitnya satu pengetahuan dengan pengetahuan yang lain melalui satu hubungan yang saling menghargai dan saling mempertimbangkan. Secara lebih jauh integrasi-interkoneksi sain dan agama adalah suatu usaha keniscayaan terpadunya sains dan agama dalam kajian yang berdasarkan metode ilmiah yang dapat dipertanggungjawabkan atau saling keterkaitan dan dialogis untuk saling mengisi antara sain dan agama (Amril, 2016). Makna integrasi ilmu secara lebih praktis merupakan ketinggian dan kemampuan seseorang dalam penguasaan sains disertai dengan tingginya profesionalisme berhubungan erat dengan akhlak dan penguasaan peradaban Islam.

Pendekatan integratif pandangan Amin Abullah adalah terpadunya kebenaran wahyu (burhân ilahî) atau nash (hadharah al-nash), dengan bukti-bukti yang ditemukan di alam semesta ini (burhân kawnî) empiris-kemasyarakatan dan kealaman (hadharah al-ilm), dan (hadharah al-falsafah). Sementara pendekatan interkonektif adalah terkaitnya satu pengetahuan dengan pengetahuan yang lain melalui satu hubungan yang saling menghargai dan saling mempertimbangkan, dan saling sapa, saling dialog atau saling melengkapi antar sain dan agama (Amin,

Jurnal At-Tafkir: Volume 13 Nomor 1 Tahun 2020

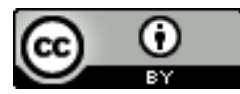

This work is licensed under a Creative Commons Attribution 4.0 International License 


\section{ب.}

2006) dan pemahaman keagamaan. Sasaran integrasi-interkoneksi adalah menghilangkan dikotomis sains dan agama.

Integrasi dan Dialog Sain dan Agama Ian. G. Barbour

Barbour menemukan banyak fenomena sejarah masa lalu kalangan ilmuwan dan rohaniawan gereja melihat bahwa ilmu pengetahuan dan agama sebagai dua kutub yang bertolak belakang yang pada dasarnya tidak berhubungan satu sama lain (Habibi, 2016). Seperti yang telah disebutkan di atas bahwa konflik dikalangan Kristen ortodok dan ilmuan tentang kosmologi maka Ian Barbour mengelompokkan keberadaan sains dan agama pada empat tipologi yaitu konflik, independ, dialog dan integrasi (Barbour, 2002).

Pandangan beliau yang pertama adalah konflik. Konflik adalah antara sains dan agama tidak bisa di satukan dan keduannya adalah saling bertentangan. Para ilmuwa tidak mau mengakui keberadaan bahkan tidak percaya agama, karena agama tidak mampu menjelaskan dan memberikan verifikasi terhadap sain yang emperik, rasional dan positivistik. Cara pandang sain dan agama sangat kontras dan betentangan antara sain dan agama memiliki cara pandang yang berlawanan, masing-masing mengokokohkan eksitensinya. Peristiwa kontras dan berlawanan dapat dilihat dari peristiwa pertentangan antara gereja dan ilmuwan sebelum masuk pada era renaissance, contoh yang lebih konkrit adalah pernyataan Darwin dan Laplace terhadap teori masing-masing. Karekater agama sifatnya subjektif, tertutup dan sulit berubah, sedangkan sain positivistic, dapat diukur, tetapi sain tidak dapat menjelaskan, mengukapkan transformasi kehidupaan manusia.

Kedua adalah independen, menyatakan bahwa sains dan agama dua kebenaran yang terpisahkan. Antara agama dan sain mengakui akan kebenaran masing masing-masing, mengakui eksistensinya masing-masing, sain dan agama memiliki autoritas dan keduanya memiliki kebenaran sendiri-sendiri. Pemahaman agama subjektif, transededntal akan pengungkapkan diri. Sedangkan sains adalah yang paling berhak menerangakan ilmu dengan fakta-fakta ilmiah, sedangkan agama menerangkan ilahiyah. Tidak bisa disatukan keduanya, masing-

Jurnal At-Tafkir: Volume 13 Nomor 1 Tahun 2020

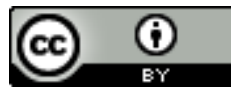

This work is licensed under a Creative Commons Attribution 4.0 International License 


\section{$r<$}

masing menunjukan egonya. Namun keduanya mengakui akan kebenaran masing-masing, keduanya memiliki autoritas untuk menyatakan kebenaran sendiri-sendiri.

Ketiga pandangan Barbour keterkaitan sain dan agama adalah dialog. Dalam pandangan Barbour dialog adanya jalan untuk mengkomunikasikan antara sains dan agama (Mahzar, 2005) antara sain dan agama terdapat hal-hal yang bisa didialogkan, dan bahkan bisa saling membantu mendukung. Paradigma ilmu dialogis dapat diartikan cara pandang terhadap ilmu-ilmu sekuler, dan banyak informasi ilmu pengetahuan dapat bersumber dari agama dapat saling mengisi secara bersama dan konstruktif. Pandangan ini memahami bahwa ada keterkaitan antara sains dan agama dan sangat dimunkinkan saling mendukung dan bisa saling membantu. Paradigm dialogis dapat diartikan cara pandang terhadap ilmuilmu sekuler dan ilmu yang bersumber dari agama dapat saling mengisi secara konstruktif, antara ilmuwan dan kaum agamawan dapat bekerjasama.

Keempat adalah pandangan Barbour adanya integrasi antara sains dan agama. Menurut Barbour dalam upaya integrasi ada 2; Natural teology dan theology of natural. Pertama, natural teology eksistensi Tuhan dapat disimpulkan dari atau didukung dengan data-data ilmiah, semakin mengetahui eksistensi Tuhan. Dalam teori natural theology semua yang ada di alam ini baik itu bentuk, tata tertib/hukum alam dan keindahan serta kompleksitas alam mendukung adanya grand desain dibalik semua itu. Eksitensi Tuhan bisa dimanefestasikan dari wujud dan desain alam merupakan akan tanda eksistesi Tuhan. Kedua Theology of natural sumber utama teologi terletak diluar sain, tetapi teori-teori ilmiah bisa digunakan untuk perumusan ulang doktrin-doktrin tertentu, oleh sebab itu teori of natural membantu untuk menelaah ulang atau mereformulasi doktrin doktrin agama yang sudah mapan untuk pemahaman ilmiah. Maksudnya adalah memberikan teori yang lebih komprehensif terhadap teori agama dengan bantuan rumusan sain (Barbour, 2002). Dalam pemahaman ini integrasi bahwa agama dan sains memiliki validitas yang koheren dalam pandangan dunia. Kedalaman pemahaman 


\section{(I)}

tentang fisik diperoleh sain dapat memperkaya pemahaman keagamaan bagi manusia yang beriman

\section{PEMBAHASAN DAN ANALISA}

Jika merujuk kepada latarbelakang kedua tokoh tersebut Amin dan Barbour bahwa mereka melihat suatu kesenjangan dan konflik dan mengklaim akan superiotitas bangun keilmuan masing-masing. Amin melihat adanya kesenjangan perkembangan keilmuan yang berkembang saat ini khususnya di dalam negeri, baik itu di perguruan tinggi Agama maupun diperguruan tinggi umum,bahkan di level pendidikan menengah termasuk pesantren. Satu sisi perkembangan ilmu sangat mengikuti rasionalisasi Barat menyamainya untuk dijadikan platform sebagai alternatif pemecahan masalah kehidupan justru tidak menyelesaikan tapi menimbulkan masalah baru termasuk keraguan atas agamanya sendiri.

Amin menginginkan ilmuwan-ilmuwan berkarakter dan memilki integritas keilmuan yang yang baik dan kokoh melalui bangunan keilmuwan interconnected entities yaitu mengkoneksikan ulumuddin dan sain untuk saling mengisi yang berwatak teoatroposentris integralistik yang beliau skema dengan jaring laba-laba, pure sain-applied science dengan tidak memisahkan keduanya. Karena sesunguhnya sumber ilmu pengetahuan itu ada dua macam yaitu berasal dari Tuhan dan yang berasal dari manusia dalam istilah Kontowijoyo dediferensiasi menyatukan kedua ilmu tersebut. Usaha tersebut selalu disebut dengan integrasi ilmu.

Rekayasa bangunan keilmuwan yang ditawarkan Amin seirama dengan model yang disampaikan oleh Ian Barbour dengan model integrasi dan dialog antara sain dan agama. Barbor menawarkan pendekatan diaolog dan integritas. Mendialogkan bisa juga berarti membandingkan antara informasi sain dan agama. Pendekatan dialog dan integritas tersebut juga di gunakan Amin dalam meredakan domain-domain superioritas keilmuan. Amin dan Borbour mendialogkan sain dan agama, jika Barbour pendekatan dialog dan integrasi. 
Dialog ilmu dan sain adanya objek-objek bisa didialogkan akan membantu kesamaan pandangan dan akan bahkan bisa saling mendukung. Dalam contoh kasus tertentu tentang penciptaan manusia dan alam semesta, tokoh agama bisa menjadi mitra dialog bagi ilmuwan. Jika baorbour menggunakan Istilah dialog dalam pendekatannya, Amin menggunakan istilah integratif yaitu memadukannya antara kebenaran wahyu hadrah al-nash dengan bukti-bukti ilmiah burhan kawni dalam bidang ilmu kealaman (hadrah al-ilm) serta mengaitkan dengan pembelajaran etis (hadrah al-falasifah).

Sedangkan integrasi bagi Barbour adalah antara sain dan agama informasi dari agama dan sain saling menguatkan, memberikan pandangan yang lebih menyakinkan terhadap sain dan agama itu sendiri karena keduanya memberikan pandangan dan wawasan yang lebih mendalam terhadap sain dan agama. Integratif ilmu merupakan bantuan informasi saling menambah keyakinan akan kebenaran Tuhan untuk diimani. Bagi Amin ini ia pakai dengan istilah interkoneksi dengan integrasi menutupi kekurangan dari domain masing-masing untuk saling melengkapi.

\section{KESIMPULAN}

Amin Abdullah dan Ian G. Barbour adalah tokoh ilmuwan yang memberikan sumbangan pemikiran rumusan ulang terhadap kegelisahan terhadap konflik antara doktrin agama dan sain dalam suasana dan alasan yang berbeda. Keduanya menunjukan kapasitasnya masing-masing dengan brandnya sebagai solusi sangat detail terhadap konflik tersebut.

Ada dua pendekatan yang diusulkan oleh Ian G. Barbour yaitu dialog dan Integrasi. Dialog membangun komunikasi yang bersifat konstruktif dan harmonis antara sain dan agama dibandingakan konflik dan idependen, karena dialog bisa saling mendukung dan bekerja sama, sama-sama melihat pra konsep dan metode membandingkan yang memahami perbedaan dan persaman. Integrasi Barbour Untuk menunjukan eksitensi Tuhan bisa dilihat dari pada keteraturan alam, desain alam yang menunjukan akan eksistensi Tuhan apa yang beliau tawarkan 


\section{난}

dengan pendekatan integrasi versi Natural theology. Natural theology berangkat dari data ilmiah untuk memahami eksitensi Tuhan. Sedangkan versi theology of nature barbour membantu untuk memeriksa atau memberikan formulasi baru terhadap pemahaman doktrin agama menurut sain. Secara lebih konkrit theologi of nature membantu merumuskan ulang teori -teori doktrin agama dengan bantuan sain.

Pendekatan integrasi dalam pandangan Amin adalah menyatunya kebenaran wahyu dengan bentuk pembindangan mata kuliah terkait dengan (hadrah al-Nash) dengan bukti-bukti di alam semesta (hadrah al-ilm) ilmu kealaman danjuga tidak bisa dilepas mata kulaih hadrah al-falsafah. Interkoneksi ingin menyambungkan atas keterbatasan menyelesaiakan fenomena kehidupan yang komplesitas, keberagaman bahwa tidak itu diselesaikan sendiri, interkoneksitas meleburkan diri dari berbagai cara pandang historis dan normativitas dan sakralitas. Interkoneksitas menawarkan cara pandang dunia (world view) atau terbuka. Interkoneksitas secara lebih khusus ada menghilangkan blok-blok teksteks (hadrah al-Nash) budaya kitab, dengan (hadrah al-ilmu) serta budaya etisfilosofis (hadrah al-falsafah) dengan saling dialog sebagai cara pandang terhadap ilmu yang terbuka dan menghormati keberadaan jenis-jenis ilmu yang ada secara proposional dengan tidak meninggalkan sifat kritis.

\section{DAFTAR PUSTAKA}

Azra, Azyumurdi, Pendidikan Islam Tradisi di Tengah Tantangan Milenium III, edisi pertama, Cetakan Ke-2, Jakarta : Kencana PRENADAMEDIA GROUP, 2104.

Abdullah, Amin, Islamic Studies di Perguruan Tinggi Pendekatan IntegratifInterkonektif, Yogyakarta: Pustaka Pelajar, 2006.

..................-, Transformasi IAIN Sunan Kalijaga menjadi UIN Sunan kalijaga, Lapaoran Petanggungjawaban Rektor Universitas Islam Negeri Sunan Kalijaga Periode Tahun 2001-2005.

Amril, Epistimologi Integratif-Interkonektif. Agama dan Sains (Menggali Potensi-konsepsi Menuju Teori-Aplikasi dalam pengembangan ilmu Keislaman dan pembelajaran), Jakarta, Rajawali Pers, 2016.

Abduh, Muhammad, Ilmu Menurut Peradaban Islam dan Kristen, (Bandung Diponegoro) 1992. 


\section{난}

Barbour, Ian G, Juru Bicara Tuhan; antrara sains dan Agama, Bandung: Mizan, 2002 Hornby. Oxford Advanced Leaner's Dictionary, International Student Edition, (NewYork: Universitu of Oxford), 2015.

Mulyadhi, Kartanegara, Mengislamkan Nalar, Sebuah Respon terhadap Modernitas, Jakarta: Erlangga, 2002.

Mulyadhi, Kartanegara, Integrasi Ilmu, Sebuah rekonstruksi Holistik, Jakarta: UIN Jakarta Press, 2005.

Mizan, Habibi, Moh. Jurnal El-Tarbawi Jurnal Pendidikan Islam, Volume IX, No.l, 2016.

Mahzar, Armehdi, Integrasi Ilmu dan Agama Interprestasi dan Aksi, ( Bandung:Mizan, 2005)

Nasution, Hasyimsah, Filsafat Islam, (Jakarta: Gaya Media Pratama,1999

Oey-Gardiner, Mayling et.al. Era Disrupsi Peluang dan Tantangan Pendidikan Tinggi Indonesia, AIPI (Jakarta: Akademi Ilmu Pengetahuan Indonesia 2017),

Kusmana, Integrasi Keilmuan UIN Syarif Hidayatullah Jakarta Menuju Universitas Riset. Jakarta : PPJM dan UIN Jakarta Press, 2006.

Surat Usulun Menteri Agama RI tanggal 23 Januari 2004 kepada MENPAN perihal usulan Perubahan IAIN Sunan kalijaga Yogyakarta menjadi UIN dan STAIN Malang Menjadi UIN.

Tjasyono, Bayong dan Muhamad Syukur, Keajaiban Planet Bumi. Dalam Perspektif Sains dan Islam, (Bandung: Rosdakarya) 2014.

Team, Kerangka Dasar Ke-ilmuan dan Pengembangan Kurikulum, (Yogyakarta: Akademik UIN SUKA, 2006.

UU Sistem Pendidikan N0. 20 Tahun 2003. 1Bab 1 ketentuan Umum pasal 1

Putra Daulay, Haidar, Kontribusi Ormas Dalam Mewujudkan Umat Islam Berkeunggulan di Abad ke 21, Cet. Pertama, (Medan: Perdana Publishing) 2015. 